\title{
Student-Athlete Educational Records? The Involvement of FERPA Within Recent NCAA Division I Academic Scandals
}

\author{
Matt R. Huml \\ Texas Tech University
}

\author{
Anita M. Moorman \\ University of Louisville
}

\begin{abstract}
The Family Educational Rights and Privacy Act (FERPA) was enacted in 1974 to protect the privacy of student academic records (FERPA, 2015). FERPA restricts the disclosure without consent of certain student records, files, documents, and other materials managed by educational institutions (U.S. Department of Education, 2004). Athletic departments have been criticized for expanding these rules to protect themselves in times of academic scandals (Escoffery, 2014; Riepenhoff \& Jones, 2009; Salzwedel \& Ericson, 2003). This study investigated the use of FERPA during two recent academic scandals involving Division I universities' athletics programs: the University of North Carolina and the University of Notre Dame. Both universities were investigated for student-athlete academic dishonesty and employed different paths when disseminating information to the public demonstrating the ambiguous and inconsistent application of FERPA. Recommendations for universities faced with implementing FERPA to protect student records are included.
\end{abstract}

Keywords: intercollegiate athletics, academic records, athletic scandals, athletic administration

The Family Educational Rights and Privacy Act of 1974 (FERPA) provides privacy protections for student's educational records. FERPA was considered necessary to protect rights of students and parents and to prevent abuse or misuse of student data and records by federally assisted educational programs. Specifically, FERPA provides students, and parents in specific situations, the right to review institutionally maintained educational records, as well as the right to request a modification for any incorrect records (U.S. Department of Education, 2014a; O'Donnell, 2002). FERPA originally was intended to protect student files such as grades and test scores, but the scope of FERPA has since been expanded (Penrose, 2011). FERPA's protections now extend to a range of documents deemed

\footnotetext{
Huml is with the Dept. of Kinesiology and Sport Management, Texas Tech University, Lubbock, TX. Moorman is with the Dept. of Health and Sport Sciences, University of Louisville, Louisville, KY. Please address author correspondence to Matt Huml at matt.huml@ttu.edu
} 
"educational records." Educational records include university-maintained reports with a direct connection to the student or which contain personally identifiable information about a student, or even arguably information merely linkable to a student (U.S. Department of Education, 2011; 34 C.F.R. § 99.3(f) \& (g), 2009)).

College athletic departments have often been criticized for misusing FERPA to withhold records that are not protected when a student-athlete or the athletic department is subject to inquiry (Riepenhoff \& Jones, 2009). Riepenhoff and Jones reported multiple instances where documents were not produced or were heavily redacted before they were produced, including passenger lists for football team flights, complimentary ticket distribution lists, and correspondence with the NCAA related to potential NCAA violations. Given this tendency of universities to avoid disclosure requests involving student-athletes, this paper examines specific university responses to information requests in the wake of academic scandals involving student-athletes. It is anticipated that, consistent with previous tendencies to limit disclosure, the universities would similarly use FERPA to avoid disclosure of information in any way connected to the alleged academic fraud or misconduct.

The academic success of student-athletes has been an area of significant interest and scrutiny since the advent of the National Collegiate Athletic Association (NCAA). Academic performance and progress of student-athletes have been studied by researchers and academics (Adler \& Adler, 1991; Comeaux, 2013; Crowley, 2006; Hood, Craig, \& Ferguson, 1992; Huml, Hancock, \& Bergman, 2014) and closely covered by the media (Wolverton, 2008, 2015). Research has highlighted concerns over student-athletes not being prepared for the academic rigors of higher education compared with their student peers (Benson, 2000; Gaston-Gayles \& Hu, 2009). However, universities and the NCAA often champion how certain studentathlete academic performance factors (e.g., graduation rate) have now surpassed the general student body (NCAA, 2011; New, 2014), further increasing the attention on student-athletes and their academic experience. With the academic success of student-athletes continuing to attract great focus, universities may benefit from invoking FERPA laws in an effort to prevent academic transgressions incurred by student-athletes from being publicly released (Escoffery, 2014; Krebs, 2013; Penrose, 2011; Riepenhoff and Jones, 2009).

The purpose of this study is to examine the use of FERPA by universities experiencing an academic scandal and investigation by the NCAA. The two universities chosen, the University of North Carolina (UNC) and the University of Notre Dame, have been investigated for academic dishonesty involving student-athletes. While several legal scholars have examined the application of FERPA in secondary and higher education settings (Daggett, 2008; Penrose, 2011), there is little comparative research related to how universities use FERPA to protect/release information during investigations involving student-athletes. This paper will examine the background and characteristics of FERPA and review cases involving FERPA within intercollegiate athletics. Next, an evaluation will be presented of the case studies on the University of North Carolina and the University of Notre Dame to observe these universities' utilization of FERPA, recurring themes within their handling of information requests, and recommendations for the future. 


\section{FERPA and Student-Athlete Educational Records}

This section will provide a summary of FERPA, review prior literature, and discuss court cases where student-athletes, coaches, and/or athletics programs were the focus of information requests or disclosures implicating FERPA.

\section{Summary of FERPA and Student Educational Records}

FERPA, also known as the Buckley Amendment after its chief sponsor, New York Senator James Buckley, was signed into law in 1974 (U.S. Department of Education, 2004). FERPA applied to any educational institution receiving federal financial assistance and conditioned the receipt of federal funding on schools' agreement to permit parents and students 18 or older access to their records (20 U.S.C. $§ 1232 \mathrm{~g}$ ). In 2002, the United States Supreme Court held students were not provided a private right of action under FERPA (Gonzaga University v. Doe, 2002). The Supreme Court reasoned that the creation of individual rights required clear and unambiguous terms, which are not present in FERPA's provisions. FERPA's nondisclosure provisions do not contain any rights-creating language according to the Supreme Court. Thus, instead of seeking a private remedy, students must file a complaint through the Family Policy Compliance Office (FPCO) at the Department of Education or pursue state privacy laws (U.S. Department of Education, 2014b). The only federal penalty for universities violating FERPA is a loss of federal funding (U.S. Department of Education, 2014b), which has never occurred in the history of FERPA (Daggett, 2008).

FERPA originally enumerated a specific list of protected records, including grades, attendance records, test scores, teacher/counselor ratings, and health information. That list was then replaced with a general description of "educational records," which includes records, files, documents, and other materials containing information directly related to a student and maintained by an educational institution (20 U.S.C. $\$ 1232$ g(a)(4)(A) (2015)). Congress amended FERPA in 1992, expressly removing privacy protections for police and campus security for records created for the purpose of law enforcement. Congressional statements in 1992 confirm that an educational record was and is intended to encompass records maintained by the institution for students in the normal course of business and used by the institution in making decisions affecting the life of the student (Student Press Law Center, n.d.). FERPA was amended again in 1998, specifying that disciplinary outcomes involving crimes of violence or sex crimes were excluded from FERPA's protections. The implication is that all other disciplinary outcomes would still be protected under FERPA, such as those related to academic misconduct (Student Press Law Center).

To be protected, the educational records must contain personally identifiable information, including direct identifiers, such as a student's or parents' names or address, social security or student number, or indirect identifiers, such as date or place of birth, mother's maiden name, or information a reasonable person could link to a specific student (34 C.F.R. $\$ 99.3$ (2014)). In the context of student-athletes, the "linkability" of information to specific athletes is of particular concern because 
of their high visibility at many universities. Their names are prominently featured in athletic department websites, media guides, and other informational or promotional communications. Thus, if a student-athlete is dismissed or suspended from team activities, their absence is noticeable to the general public and media outlets seeking information about the athlete's status. Thus, even an acknowledgment of an academic misconduct inquiry can effectively "link" a student-athlete to the inquiry in ways a traditional student would likely not experience.

Even though FERPA provides privacy protections to students, most litigation triggering a FERPA claim by the university is typically initiated by a media outlet that has sought access to university records under various state open-records acts. Open-records laws (also known as public records laws, sunshine laws, or freedom of information statutes) permit inspection and copying of documents maintained by public and government agencies. Open-records laws are intended to provide transparency in government so that citizens can know how public officials are conducting public business. Public oversight is believed to help deter corruption, undue influence, and misconduct. Thus, all public universities, colleges, and schools are subject to the state open-records laws in the states in which they are located.

Each state stipulates specific guidelines for public agencies to follow in maintaining and disclosing information for the public. Each state's public records law is specific to that state and may vary significantly from one state to the next in terms of the breadth of exemptions and disclosure response deadlines (FOIAdvocates, 2016). Interestingly, the Georgia State Senate has proposed extending the time for athletic departments to respond to open-records requests from 3 days to 60 days, partially in response to concerns expressed by the Athletic Department that its staff was overwhelmed by the significant volume of requests they received daily (Foody $\&$ Phillips, 2016). The proposed Georgia amendment is a fairly extreme departure from state open-records laws, which are generally given a broad application to maximize public access to information.

The relationship between FERPA and state open-records law can be unclear. For example, a state university is subject to its state open-records law and it is also charged with protecting private student information under FERPA. Therefore, universities will assert FERPA as an exemption to disclosure and refuse to produce records in response to an open-records request, asserting that the records are protected documents under FERPA. However, even documents that may contain some protected student information must still be produced if the identifying information can be removed. Once the student's identifying information is redacted, the document ceases to be a FERPA "education record."

With any decision regarding the release of information, the university must determine whether information (a) must be released upon request, (b) must not be released, or (c) may be released or not based on the university's policies and practices (Hughes, 2000). Navigating situations involving student-athletes is particularly challenging due to the intense public interest and scrutiny of athletic departments (Wolverton, 2008, 2015).

\section{FERPA and Student-Athletes' Educational Records}

Research has also shown that university athletic departments use FERPA to refuse releasing information on student-athletes who encounter academic difficulties (e.g., 
academic suspension, cheating, ineligibility), but willingly release stories on their academic success (Batista, 2004; Strentz, 2001). Several scholars and media outlets have challenged whether universities are misusing FERPA's privacy requirements to aid the university to avoid disclosure of documents that, if revealed, would cast the university and its athletic programs in a negative light (Krebs, 2013). Strentz (2001) believes an institution will provide an outside participant with requested records by deciding whether the records will make the school look good or bad. Strentz noted Drake University's refusal to report the grade point average (GPA) of student-athletes academically suspended from the basketball team, but that university released information on athletes reaching a certain level of academic success (e.g., 3.0 or higher).

A similar situation occurred at Iowa State University ("FERPA Student-Athletes," 1998). The athletic department released the names of student-athletes who achieved a GPA of 3.0 or higher. The editor requested the remaining names and GPAs of student-athletes not on the list. Iowa State University refused the request and subsequently changed their student-athlete forms to revise language allowing the athletic department to release information only about academic excellence ("FERPA Student-Athletes," 1998). The cases, discussed below, have produced inconsistent guidance related to student-athlete academic and nonacademic conduct constituting "education records" covered by FERPA.

In Kirwan v. The Diamondback (1998), a local media company requested records for an NCAA investigation into University of Maryland student-athletes illegally parking on campus and the university providing preferential treatment regarding their parking fines. The University of Maryland refused to release this information to the local newspaper, claiming parking tickets were protected "academic records" under FERPA. The Court of Appeals of Maryland ruled that parking tickets did not qualify as academic records and, therefore, were not protected by FERPA (Kirwan v. The Diamondback, 1998). In NCAA v. Associated Press (2009), the Florida District Courts of Appeal held that documents Florida State University received related to an ongoing NCAA investigation into alleged improper assistance provided to student-athletes were public records received in connection with the transaction of official university business. Therefore, the records were subject to disclosure under Florida's state open-records law (pp. 1204-06).

Conversely, in United States v. Miami University (2001) and State ex. rel ESPN, Inc. v. Ohio State University (2012), both the United States Sixth Circuit Court of Appeals and the Ohio State Supreme Court adopted a broader definition of "education records." In United States v. Miami University, the Chronicle of Higher Education had requested all disciplinary records from 1995 to 1996 from Miami University and Ohio State University. The universities planned on releasing the information based on a previous decision of the Ohio Supreme Court holding that FERPA did not protect disciplinary records (State ex. rel The Miami Student v. Miami University, 1997). The Department of Education obtained an injunction preventing the disclosure, arguing the information would contain personally identifiable information protected under FERPA. On appeal, the Sixth Circuit affirmed the District Court's decision and held that student disciplinary records are education records under the plain language of FERPA and are protected because they relate directly to the student and are kept by the university (Miami, p. 812). As mentioned previously, Congress amended FERPA in 1998 to clarify that student disciplinary 
records related to violent crimes and sex crimes are not protected by FERPA. Thus, the Sixth Circuit's decision as it relates to other student disciplinary records still represents the majority position that disciplinary records are protected. However, this is an area where courts have reached conflicting decisions.

The Ohio State Supreme Court extended the scope of education records even further in State ex rel. ESPN, Inc. v. Ohio State University (2012). ESPN requested e-mails, letters, and memos related to football players and coaches who had been implicated in the Ohio State tattoo scandal. The court followed the Sixth Circuit's holding in Miami University, according to which student disciplinary records were education records, and stated that education records are not restricted to just documents relating to academic performance or financial aid (ESPN, pp. 946-947).

These cases demonstrate the ambiguity and inconsistency encountered when one is confronted with information disclosures related to NCAA investigations and student-athlete misconduct. Educational records such as student grades, academic performance, and university disciplinary hearings are consistently protected under FERPA. However, NCAA investigative findings, conclusions and hearings, settlements, litigation documents, e-mails, and correspondence related to student-athlete misconduct have produced mixed results. Before the decision in ESPN v. Ohio State, one could navigate the release of e-mails, correspondence, and NCAA or university investigative documents by redacting any personally identifying student information. However, the ESPN v. Ohio State decision adopted a much broader protection for information related to investigations involving student-athletes.

With these legal precedents regarding FERPA and athletic departments' tendency to not release disparaging information about athletics in general, universities may lack both the clarity and, perhaps, the requisite motivation to assess which records can be released to outside constituents.

\section{Purpose of the Study and Methodology}

The purpose of this study is to examine the use of FERPA by two institutions facing academic transgressions by student-athletes. This section will examine their unique situations, whether FERPA was used to refuse disclosure of information, whether FERPA-protected information was disclosed in error, and whether these decisions align with the legislation. The authors applied a purposive sampling technique to identify potential institutions for the study. Purposive sampling was used to correctly target athletic departments under investigation, or recently investigated, by the NCAA involving academic records. This approach is also necessary to allow researchers to replicate a similar approach within a different subset of the population (Yin, 2003). The unique population for this study are two athletic departments under NCAA investigation for conduct performed by student-athletes that would potentially be protected by FERPA. In addition, this technique is appropriate when the study is describing events from a specific period of time in greater depth than traditional studies (Yin, 2003). While utilizing a purposive sampling technique was necessary for this study, it limits the generalizability of the findings to other institutions under NCAA investigation for student-athlete academic misconduct (Dillman, Smyth, \& Christian, 2009). Data will be analyzed to examine the effectiveness and consistency of universities'/athletic departments' not reporting protected academic 
records and/or releasing information that is not FERPA protected to public entities. The themes presented in the discussion section were chosen to align with previous research into concerns about athletic departments utilizing FERPA (Batista, 2004; "FERPA Student-Athletes," 1998; Strentz, 2001).

\section{Case Analysis of University FERPA Claims}

For the purpose of this study, an analysis was performed on numerous documents related to recent academic scandals at the University of North Carolina and the University of Notre Dame. These materials included court documents, media articles, university press releases, transcripts of press conferences, and NCAA documentation related to rules infractions. The authors reviewed these materials for two unique actions: (a) an institution incorrectly asserting that FERPA protects certain information, which prevents said information from being released to another party (e.g., claiming parking tickets as educational records) or (b) an institution violating FERPA by releasing protected information directly related to a studentathlete in connection with academic performance.

\section{University of North Carolina}

In 2011, the NCAA began an investigation into the University of North Carolina regarding a former tutor committing academic fraud and the unethical conduct of an assistant football coach (NCAA, 2012). This investigation was concluded on March 12, 2012, leading to vacating all athletic records during the 2008, 2009, and 2010 football seasons, loss of 15 football scholarships for a three-year period, a $\$ 50,000$ self-imposed financial penalty, and a one-year ban of postseason football (NCAA, 2012).

As details of the investigation became public knowledge, local media members began requesting additional information from the University of North Carolina through a Freedom of Information Act (FOIA) request (Hardin, 2011). While UNC did provide some of the information requested, it refused to release information on six different categories requested by The News \& Observer, Charlotte Observer, News 14 Carolina, WTVD Television, The Associated Press, and Media General Operations (hereinafter "media plaintiffs"; Hardin, 2011). These categories included (1) names of individuals/organizations who provided impermissible benefits to football student-athletes; (2) names of student-athletes on athletic scholarship; (3) records of the university's investigation of any football coach, football student-athlete, sports agent, university booster, or academic tutors available to student-athletes; (4) phone numbers on telephone bills for the university's athletic director (Richard Baddour), head football coach (Butch Davis), and associate football coach (John Blake); (5) parking tickets issued to eleven student-athletes on the football team; and (6) employment information on tutors/mentors used by the athletic department. UNC asserted that releasing this information would be a FERPA violation (The News \& Observer Publishing Co. v. Baddour).

Following the UNC's refusal to release the records, the media plaintiffs filed a writ of mandamus to compel the university to release the information (Hardin, 2011). At the hearing, the university willingly provided information on categories 
one (student-athletes receiving impermissible benefits) and two (student-athletes on scholarship), while both parties agreed to postpone a decision on category three (NCAA investigation) until the investigation had been concluded (The News \& Observer Publishing Co. v. Baddour, 2011). The information from categories one and two are exempted under FERPA as directory information; thus, UNC eventually agreed to release the information. This contention from UNC, followed by a negotiated release, is consistent with prior observations within the literature (Kirwan v. The Diamondback, 1998).

Next, the court reviewed information categories four, five, and six. The court issued the writ for categories four (phone calls from athletic director and football coach) and five (parking tickets), concluding that the information pertaining to these categories did not qualify as protected under FERPA (The News \& Observer Publishing Co. v. Baddour, 2011). The court reasoned that the phone records requested (category four) did not seek information on the content of the phone call, and any student's telephone numbers appearing on the record would be public information regardless; therefore, such records were not protected by FERPA. In addition, the court did not agree with the UNC's perspective of parking tickets being educational records. The court's ruling mentions that the action can only be protected if the university had disciplinary action following the athlete's ticket (The News \& Observer Publishing Co. v. Baddour). The court's decision is consistent with Kirwan v. The Diamondback, 1997, as the University of Maryland was also required to release information on student-athlete parking tickets. In addition, the U.S. Department of Education's FERPA General Guidance for Students states that a student's telephone number is an educational record exception, known as a campus directory exception, which is not protected by FERPA. Thus, these refusals were inconsistent with established precedent but, as anticipated, the university still refused to produce the records, asserting an incorrect FERPA protection.

The court also denied the writ requesting information under category six (tutor information), citing FERPA (The News \& Observer Publishing Co. v. Baddour, 2011). The North Carolina Superior Court held that FERPA protected the employment information of tutors used in the athletic department. It reasoned that, because the University of North Carolina requires athletic department tutors to be active students at the university, their employment information would qualify as an educational record. A majority of courts have held that employment records involving employee misconduct and records where students are involved as alleged victims or witnesses are not FERPA protected (Student Press Law Center, n.d.). However, an Indiana court of appeals also required redaction of personally identifying information about students contained in university records related to its investigation of student-athlete mistreatment by basketball coach Bobby Knight (Unincorporated Operating Div. of Ind Newspapers v. Trustees of Ind. Univ., 2003). Thus, UNC's FERPA claim aligns with the universities' interpretation of FERPA as it relates to student employment information.

With regard to category three, the court postponed a decision until the NCAA investigation was completed. Prior decisions have held that information related to NCAA investigations is a public record and not protected under FERPA, especially when student-athlete names or identifying information is redacted (see NCAA $v$. Associated Press (2009) and Kirwan v. The Diamondback (1997)). Consistent with these decisions involving ongoing and/or completed NCAA investigations, the 
information on student-athletes who received impermissible benefits had already been communicated from UNC to the NCAA (NCAA, 2012). Following the conclusion of the NCAA investigation in March 2012, the court reviewed the original request for a release of documentation pertaining to the university's NCAA investigation (The News \& Observer Publishing Co. v. Baddour, 2012). As in the previous hearing, the University of North Carolina stated it refused to release documents it believed to be protected by FERPA. The court decided to issue the writ for category six, ruling that the documentation pertaining to the NCAA investigation is not protected by FERPA. Specifically, since the investigation reviewed impermissible benefits received by student-athletes, the court did not perceive this situation to qualify as academic records, stating, "This kind of behavior does not relate to the classroom, test scores, grades, SAT or ACT scores, academic standing or anything else relating to a student's educational progress" (The News \& Observer Publishing Co. v. Baddour, 2012, p. 6). Following the university's second defeat of arguing FERPA-protected athletic department documents, a settlement was reached between the media plaintiffs and the University of North Carolina. The university would release the documentation to the plaintiffs and pay two thirds of their legal costs, while both parties agreed to not appeal the court's decision (McGowan, 2012).

Following the conclusion of the official NCAA investigation, the University of North Carolina experienced two separate incidents of an accidental public release of a student-athlete's transcript. First, an academic transcript for an NCAA-investigated football player was reported by a local news outlet, The News \& Observer (Kane, 2011). It showed that the student-athlete registered for a 400-level course in the African-American Studies program during his first semester at University of North Carolina, earning a $\mathrm{B}^{+}$(Kane, 2011). It was from this transcript that the university and media began investigating the African-American Studies program and discovered "ghost" classes (classes with students enrolled and an instructor assigned to it but in which no or little academic work was done), rampant plagiarism, and forged signatures on grade change forms (Wainstein, Jay, \& Kukowski, 2014).

In August 2012, it was discovered that a transcript of a former football player, Julius Peppers, was publically released on the University of North Carolina's website (Hartness, 2012). Once the availability of Pepper's transcript was published by various news outlets, UNC removed the transcript from its website. While the university refused to comment on the transcript, stating any comment would violate FERPA, Peppers confirmed the transcript was genuine ("Julius Peppers Transcript," 2012). Regardless of how the transcript was posted, it is a violation of FERPA, further highlighting the inadequacy of remedies available to students whose confidential records are either intentionally or inadvertently released to the public.

Following the discovery of the academic scandal originating in the AfricanAmerican Studies program, media outlets again began requesting information. The News \& Observer sought records on the enrollment within the previously mentioned "ghost" classes (Zhang, 2014). The university released the records from 2006 to 2011, but would not release information before that time period (Zhang, 2014). Media plaintiffs again filed a complaint seeking a writ of mandamus to compel UNC to produce the requested information associated with the "Wainstein Report." The university originally refused to release those records, again asserting the release would violate FERPA. The plaintiffs voluntarily dismissed the complaint on December 31, 2014 (telephone communication with Wake County Clerk, 
2015). UNC's FOIA records indicate multiple information requests are still pending (University of North Carolina, 2015b). The University of North Carolina's assertion that FERPA protects information from one time period but does not protect the same information from a different time period seems inconsistent and unsupported (U.S. Department of Education, 2012). FERPA does not have any time-sensitive regulations, and it can be interpreted that once a document is protected by FERPA, it will always be protected by it.

The court decisions related to the University of North Carolina show consistency with legal precedent and previous findings within the literature regarding the use of FERPA to protect academic records of student-athletes (Batista, 2004; Kirwan v. The Diamondback, 1997; NCAA v. Associated Press, 2009; Strentz, 2001). Despite the clear legal precedent, UNC still decided to use FERPA as a blanket defense to multiple requests by media members, which were reasonably interpreted as having the potential to provide negative exposure to the university. In contrast, however, at least two separate instances were identified in which protected education records (academic transcripts) were leaked or inadvertently released to the general public.

While the University of North Carolina's academic scandal involved many media information requests and multiple legal controversies between the university and media regarding FERPA protections, the authors of the current study also wanted to examine a university (a) facing an academic scandal around the same time as was the University of North Carolina, (b) with greater protections from being compelled to release academic records, and (c) due to the greater protections, facing less pressure from the media to publically release any documentation.

\section{University of Notre Dame}

Over a two-year period, the University of Notre Dame experienced three instances of student-athletes being investigated for academic transgressions. Like UNC, Notre Dame applied FERPA to protect the release of academic records for student-athletes. But unlike UNC, Notre Dame had greater protection from releasing information due to its status as a private institution, but it still publicly released protected academic information. Starting with the Spring 2013 semester, the starting quarterback of the University of Notre Dame's football team, Everett Golson, was no longer enrolled at the institution (Hamilton, 2013). The school later confirmed to the Chicago Tribune that Golson was no longer at the University of Notre Dame due to an academic violation (Hamilton, 2013). In October 2013, Golson self-reported he used "poor judgment on a test" and disclosed that the suspension was due to him cheating on an exam ("Honor Code," 2013). When the media reached out to the football program to confirm the story, they stated they could not comment on the situation due to "privacy laws." From a FERPA perspective, the announcement of Golson no longer being enrolled at Notre Dame is allowed under FERPA. The enrollment information qualifies as a directory information exception, which includes "dates of attendance," meaning that an institution can release it without student permission (U.S. Department of Education, 2012). In contrast, the school confirming that Golson broke academic rules is a FERPA violation. This was a surprising admission, as Strentz (2001) believes universities release information only if it does not cast the institute or student-athlete in a poor light. Following Golson's admission to "poor judgment on a test," the football program correctly refused to comment on 
the situation. While it is difficult to predict what specific questions the members of the media would ask, almost every question could potentially connect to academic records protected by FERPA.

At the end of the Fall 2013 semester, a member of the men's basketball team from Notre Dame, Jerian Grant, self-reported his disenrollment at the institution due to an academic violation (Todd, 2013). Fortuna (2013) believed Grant's situation was due to an academic violation, similar to Golson's previous disenrollment. Since Grant also self-reported his disenrollment due to academics, the media was not dependent on the university making a statement; therefore, the university could avoid media questions pertaining to information protected by FERPA. Both Grant's and Golson's academic violations involved the student-athlete self-reporting their transgressions. As mentioned earlier, this self-reporting eases public pressure on universities to release details. Unlike the Golson situation, the University of Notre Dame did not confirm the reason behind Grant's disenrollment. This complies with FERPA, as the directory information exemption would allow the university to confirm his disenrollment, but not the motive.

University of Notre Dame football student-athletes were again involved in potential academic violations in August 2014 (Feldman, 2014). The university's president, Rev. John Jenkins, stated at a press conference that evidence existed of four football student-athletes submitting assignments prepared by someone else. President Jenkins also stated the university was investigating the situation and an update would be made in the future (Feldman, 2014). Near the end of August, Notre Dame's associate athletic director, John Heisler, stated a fifth Notre Dame football player was added to the list of student-athletes being investigated for academic dishonesty (Fortuna, 2014). With this being the seventh studentathlete reported as suspended from the institution within the previous 18 months, the university's athletic director, Jack Swarbick, did mention that the university reported the investigation to the NCAA (Feldman, 2014). In October 2014, Paul Browne, the university's vice president for public affairs and communications, reported that the investigation had been concluded, with the findings reported to the NCAA (Arnold, 2014). Mr. Browne also mentioned that each student being investigated was contacted regarding the university's decision on their status with the university, but that he would not be able to comment on those decisions due to FERPA (Arnold, 2014).

With the five additional football players investigated for academic violations, the university yet again released information. Notre Dame's official statement read:

On August 15 the Office of General Counsel of the University of Notre Dame notified the NCAA that because of potential ineligibility issues, the University was withholding from football participation certain student-athletes as part of an inquiry into possible academic dishonesty involving several other students as well. (Arnold, 2014)

Notre Dame's situation illustrates the challenges faced by universities when responding to media inquiries involving student-athletes and academic scandals. Based on the scope of protection identified in ESPN v. Ohio State and United States v. Miami, student-athletes are personally identifiable and linkable to ongoing academic investigations. It is troubling to see four university administrators (university 
president, university vice president for public affairs and communications, director of athletics, and associate athletic director) mention the aforementioned studentathletes were being investigated for academic dishonesty. An investigation into a student's academic dishonesty is part of his or her academic records, therefore protected by FERPA. The university twice confirming the investigation of academic violations (Golson's situation and five football student-athlete investigations) is concerning because Notre Dame is a private institution, which provides even greater protections from outside constituents making an open record's request. However, Notre Dame experienced significant criticism of its handling of the academic scandal before its attempt to diffuse the media frenzy (Arnold, 2014).

\section{Recurring Themes and Arguments Used by Universities}

When examining both the University of North Carolina and the University of Notre Dame, this review confirms that these universities overused and misused FERPA (a) to shield negative information about athletics from media and public scrutiny or (b) to release protected academic records. UNC incorrectly used FERPA to shield unprotected information and also engaged in multiple FERPA violations when releasing information to the public. Notre Dame primarily failed to recognize that the information released would violate its student-athletes' privacy protections under FERPA. Several recurring themes and arguments were identified and are discussed below.

\section{"Sacrifice the Athlete; Protect the Institution"}

These two case studies have examined academic investigations, with both the University of North Carolina and the University of Notre Dame investigating the academic dishonesty of student-athletes. Both universities were initially willing to communicate with the media what was being investigated and which studentathletes were potentially involved. And both universities released information that is FERPA protected. The most egregious release of FERPA-protected information was the public disclosure of Julius Peppers's transcript on UNC's website search engine and Notre Dame's confirmation that student-athletes were dismissed for academic misconduct.

Part of a university's willingness to provide information regarding pending academic investigations involving student-athletes may be attributed to the "celebrity" status of the student-athletes. For example, if a student-athlete is no longer participating in games and attending other public events, it is inevitable that outside constituents and the media will start to ask questions about his or her status. Because of this situation, the university may focus more on managing media inquiries and controlling the story by releasing some information about the investigation and the athletes involved rather than on maintaining the requirements of FERPA. This conduct is not uncommon among universities. For example, in Axtell v. University of Texas, Austin (2002), a student-athlete pursued litigation against that institution releasing his academic records without his permission. In retribution for that 
student-athlete communicating his displeasure toward the men's basketball coaching staff, an assistant coached intentionally faxed the player's academic records to a radio station, a clear violation of FERPA.

However, the willingness of UNC to provide information to outside constituents and the media ceased once university personnel became implicated in the internal investigation. This phenomenon may be attributed to research into the academic ability of student-athletes. There is a perception that student-athletes do not perform at the same level academically as other students in college (Benson, 2000; Gaston-Gayles \& Hu, 2009). Therefore, when a student-athlete is not academically successful, the university may deem it acceptable to disclose the investigation. This dynamic changes when the institution is implicated into the academic transgression. The academic scandal at the University of North Carolina shows that institutions become fiercely protective of their academic integrity and the public perception of them.

At Notre Dame, the situation did not reach the same level of widespread academic transgressions as it did at the University of North Carolina. In addition, as a private university, Notre Dame is not subject to the Indiana FOIA, which allows greater protections from releasing information not available to UNC. ESPN recently sought information from the University of Notre Dame Security Police Department regarding student-athlete arrest records, which was refused by the university (ESPN v. University of Notre Dame, 2015). ESPN then filed a motion for judgment to St. Joseph Superior Court, believing the university was required to release records under Indiana's Access to Public Records Act (APRA; Indiana Code § 5-14-3-1 et seq.). The court denied the motion, and dismissed the case, believing Notre Dame's status as a private organization does not require them to release information under APRA (ESPN v. University of Notre Dame, 2015).

\section{Inadvertent Releases and the "Unnamed Source"}

Another troubling finding was the recurring release of protected information either through official university information sources or through the ubiquitous unnamed source. University of North Carolina's release of transcripts on its website, while likely inadvertent, is still a FERPA violation. Julius Peppers's transcript was uploaded on a uniform resource locator (URL) address belonging to the university. This webpage was not encrypted, meaning it was publically available to anyone searching the UNC website ("Julius Peppers transcript," 2012). In addition, the transcript could be located by using UNC's homepage search engine, increasing the likelihood it could be located by anyone seeking out online athletic-related information.

In addition, the University of Notre Dame and the University of North Carolina employees potentially released FERPA-protected information to media members through "unnamed sources." Traditionally, the only two parties with knowledge of student-athletes' academic records would be the student-athletes (and their family) and university personnel. With the student-athlete having no motive to relay information on their academic transgressions publically, it seems this information is coming from an employee of the institution. Sadly, university personnel may view the "unnamed source" route as a way to avoid a FERPA violation but 
still communicate the investigation to the public. Regardless of the method, any university personnel reporting academic records to the public without the consent of the student is still a violation of FERPA.

\section{Future Recommendations}

\section{Designated FERPA Coordinator Office}

As previous research has mentioned, university personnel need to have more formalized training and available support staff for FERPA-related requests (Gilley \& Gilley, 2006). For example, the investigation at UNC led to a significant increase in requests for public records at the institution. UNC witnessed a $66 \%$ increase in FOIA requests in the past 7 years, leading to UNC's decision to hire over 9 fulltime employees to address these requests ("University Responds," n.d.). While records requests are often handled through the university's legal counsel, requests might also be made to university personnel unfamiliar with academic affairs documentation, such as athletic department personnel. The risk for the university is that many of these employees are unlikely to have training or support staff to assist in their response.

A designated FERPA coordinator office could also provide training to the athletic department on topics related to FERPA. This office would act as a liaison not only for athletic department personnel but also for any personnel within academic affairs, student affairs, faculty, and student life. Gilley and Gilley (2006) had similar thoughts when discussing recommendations for training faculty for FERPA. They believed the university experts of FERPA (registrar, legal counsel, student services) should provide direct training to faculty.

\section{University Policy for Releasing Documentation}

The authors recommend that universities craft a policy for releasing information requested by the public. This recommendation would fit together with creating a stand-alone FERPA office. Having an established policy for how to request documentation, which documentation will be made available, and the time required by the university to review the request can create an improved relationship between the institution and the outside constituent making the request. An amendment in 1996 removed the requirement that institutions have a standing student record policy (O'Donnell, 2002). This change provides the university with latitude to make a unique decision as each record's request is made. This flexibility is helpful as it pertains to FERPA, as the records protected by FERPA can range from the daily class times of students to records of visits to a counselor for mental health. When reviewing the situations involving the University of North Carolina and the University of Notre Dame, it became apparent that the availability of public information was constantly evolving as the investigations deepened. On the other hand, the lack of a policy can create further confusion for university personnel. If a staff member does not have a university policy to base their decisions on, it could lead to the unintentional release of documents protected by FERPA. 


\section{Contact at the U.S. Department of Education}

For complicated situations involving an outside party requesting university records, it would be helpful to have a contact within the U.S. Department of Education who can provide unbiased guidance on whether he or she believes the academic records will be protected by FERPA or not. When the authors contacted the U.S. Department of Education through the provided phone number on its FERPA webpage(s), there were no automated prompts allowing a caller to gather more information on FERPA or protected educational records. In addition, with NCAA scandals continuously garnering more public attention, having a connection with the U.S. Department of Education and/or the NCAA on educational records protected by FERPA would also improve an institution's response to requests.

\section{Better Utilization of FERPA by Media Members}

If members of the media are unfamiliar with the restrictions of FERPA or purposefully explore the limits of FERPA when making FOIA requests (Daggett, 2008), they may not be able to successfully request the documentation they can have access to and/or request records. For example, in the wake of the academic scandal at the University of North Carolina, the university was flooded with FOIA requests. These requests were often extremely broad both in terms of time frame and substance, such as two separate media requests for "all notes and other records of all people investigator Kenneth Wainstein and his team of investigators interviewed" and "a breakdown of enrollment in paper classes by year and by sports team . . . for 1999-2011" (University of North Carolina, 2015). These examples illustrate the breadth of some of these requests and the uncertainty surrounding whether the documents requested will contain student-athlete academic information or be linkable to particular student-athletes. A better understanding of FERPA will allow the media to ask for the correct documentation initially and to request confirmation if FERPA is used as the justification for not releasing information. This should streamline the process while also providing a foundation for the media to challenge an unsupported use of FERPA.

\section{Conclusion}

The original intention of FERPA was to grant students and parents access to records being used by educators to make decisions about students' educational opportunities. Eventually, FERPA's focus shifted to ensuring not just access for students or parents but also the privacy of education records. The recent scandals at the University of North Carolina and the University of Notre Dame will likely lead to greater scrutiny from the media on academic-related transgressions by intercollegiate student-athletes. This will require universities to be more knowledgeable about FERPA protections and information they can and cannot release publicly. An institution may attempt to shield certain information from the public's eye by incorrectly utilizing FERPA, but this may only lead to more negative publicity and greater public criticism, including from their own fan base, once a court system compels the university to release the information. 


\section{References}

34. C.F.R. § 99.3 (2009).

20. U.S.C. $§ 1232 \mathrm{~g}(\mathrm{a})(4)(\mathrm{A})(2015)$.

Adler, P.A., \& Adler, P. (1991). Backboards and blackboards: College athletes and role engulfment. New York, NY: Columbia University Press.

Arnold, K. (2014, October). With academic probe complete, Notre Dame releases statement, but not fate of players. NBC Sports. Retrieved from http://irish.nbcsports.com/2014/10/05/ with-academic-probe-complete-notre-dame-releases-statement-but-not-fate-of-players/

Axtell v. The University of Texas at Austin, 69 S.W.3d 261 (TX. Ct. App. 2002)

Batista, P.J. (2004). Student athletes and the Buckley Amendment: Right to privacy does not include the right to sue. Marquette Sports Law Review, 14(2), 319-341.

Benson, K.F. (2000). Constructing academic inadequacy: African American athletes' stories of schooling. The Journal of Higher Education, 71(2), 223-246. doi:10.2307/2649249

Comeaux, E. (2013). Rethinking academic reform and encouraging organizational innovation: Implications for stakeholder management in college sports. Innovative Higher Education, 38, 281-293. doi:10.1007/s10755-012-9240-1

Crowley, J.N. (2006). In the arena: The NCAA's first century. Indianapolis, IN: National Collegiate Athletic Association.

Daggett, L.M. (2008). FERPA in the twenty-first century: Failure to effectively regulate privacy for all students. Catholic University Law Review, 58(59), 59-114.

Dillman, D.A., Smyth, J.D., \& Christian, L.M. (2009). Internet, mail, and mixed-mode surveys: The tailored design method. Hoboken, NJ: John Wiley \& Sons.

Escoffery, E. (2014). FERPA and the press: A right to access information. The Journal of College and University Law, 40, 543-566.

ESPN v. University of Notre Dame. Order on cross motions for dismissal and judgement on the pleadings. (1501-MI-000017) (Saint Joseph Superior Court) (2015, April 20).

Family Educational Rights and Privacy Act (FERPA). (2015, June 26). Retrieved from https://www2.ed.gov/policy/gen/guid/fpco/ferpa/index.html

Family Educational Rights and Protections Act, 20 U.S.C. § 1232g; 34 CFR Part 99.

Feldman, B. (2014, August). Notre Dame dismisses four players connected to academic fraud investigation. FoxSports.com. Retrieved from http://www.foxsports.com/collegefootball/story/notre-dame-fighting-irish-081514

FERPA and student-athletes: An absurd policy (1998, April 28). The Ames (IA) Tribune. Retrieved from http://www.bloomington.in.us/-nafcar/buckley.html

FOIAdvocates. (2016). State public records laws. Foiadvocates.com. Retrieved from http:// www.foiadvocates.com/records.html

Foody, K., \& Phillips, R. (2016, March 23). Ga. open records advocates blast change for college sports. The Washington Times. Retrieved from http://www.washingtontimes. com/news/2016/mar/23/ga-open-records-advocates-blast-change-for-college/

Fortuna, M. (2013, December). Notre Dame loses leading scorer. ESPN.com. Retrieved from http://espn.go.com/mens-college-basketball/story/_/id/10182486/academics-forcenotre-dame-fighting-irish-leading-scorer-jerian-grant-leave-team

Fortuna, M. (2014, August). A fifth Notre Dame football player will be held out as investigation continues. ESPN.com. Retrieved from http://espn.go.com/college-football/ story/_id/11426695/a-fifth-notre-dame-football-player-held-investigation-continues

$\mathrm{Hu}, \mathrm{S} .$, \& Gaston-Gayles, J. (2009). The influence of student engagement and sport participation on college outcomes among Division I student athletes. The Journal of Higher Education, 80(3), 315-333. doi:10.1353/jhe.0.0051

Gilley, A., \& Gilley, J.W. (2006). FERPA: What do faculty know? What can universities do? College and University Journal, 82, 17-26. 
Gonzaga University v. Doe, 536 U.S. 273 (U.S. 2002).

Hamilton, B. (2013, May). Door could be open for QB Golson's return to Notre Dame. Chicago Tribune. Retrieved from http://articles.chicagotribune.com/2013-05-26/sports/ chi-everett-golson-notre-dame-20130525_1_qb-golson-everett-golson-tommy-rees

Hardin, N. (2011). UNC will appeal FERPA ruling ordering disclosure of athletic department records. Student Press Law Center. Retrieved from http://www.splc.org/blog/ splc/2011/05/unc-will-appeal-ferpa-ruling-ordering-disclosure-of-athletic-departmentrecords

Hartness, E. (2012, August). Online transcript could bring feds down on UNC. WRAL.com. Retrieved from http://www.wral.com/news/local/story/11428957/

Hood, A.B., Craig, A.F., \& Ferguson, B.W. (1992). The impact of athletics, part-time employment, and other activities on academic achievement. Journal of College Student Development, 33(5), 447-453.

"Honor Code." (2013, August). Ex-Irish QB violated honor code. ESPN.com. Retrieved from http://espn.go.com/college-football/story/_/id/9899850/notre-dame-suspensiondue-poor-judgment-test

Hughes, T. (2000, Winter). Releasing student information: What's public and what's not. School Law Bulletin, pp. 1-29.

Huml, M.R., Hancock, M.G., \& Bergman, M.J. (2014). Additional support or extravagant cost? Student-athletes' perceptions on athletic academic centers. Journal of Issues in Intercollegiate Athletics, 7, 410-430.

Indiana Code § 5-14-3-1 et seq. (2014).

"Julius Peppers Transcript." (2012, August). Julius Peppers: Transcript mine. ESPN.com. Retrieved from http://espn.go.com/college-football/story/_id/8280794/julius-peppersconfirms-transcript-posted-north-carolina-tar-heels-site

Kane, D. (2011, August). Austin's UNC transcript raises questions. The News \& Observer. Retrieved from http://www.newsobserver.com/2011/08/21/1425946/uncs-austin-gotunusual-start.html

Kirwan v. The Diamondback, 721 A.2d 196 (Md. 1998).

Krebs, K. (2013). ESPN v. Ohio State: The Ohio State Supreme Court uses FERPA to play defense for offensive athletic programs. Jeffrey S. Moorad Sports Law Journal, 20, 573-954.

McGowan, B. (2012, October). UNC will release records to media group as part of settlement in FERPA case. Student Press Law Center. Retrieved from http://www.splc.org/ article/2012/10/unc-will-release-records-to-media-group-as-part-of-settlement-inferpa-case? $\mathrm{id}=2477$

NCAA v. Associated Press, 18 So. 3d 1201 (Fla. Dist. Ct. App. 2009).

NCAA. (2011). NCAA grad rates hit all-time high. Retrieved from http://www.ncaa.com/ news/ncaa/article/2011-10-25/ncaa-grad-rates-hit-all-time-high

NCAA. (2012). University of North Carolina, Chapel Hill public infractions report. Indianapolis, IN.

New, J. (2014, October 29). More athletes get to the finish line. Inside Higher Ed. Retrieved from https://www.insidehighered.com/news/2014/10/29/graduation-rates-athletes-hitrecord-high

O'Donnell, M.L. (2002). FERPA: Only a piece of the privacy puzzle. The Journal of College and University Law, 29(3), 679-717.

Penrose, M.M. (2011). In the name of Watergate: Returning FERPA to its original design. Legislation and Public Policy, 14, 75-113.

Riepenhoff, J., \& Jones, T. (2009, June). Secrecy 101: Athletic departments use vague law to keep public records from being seen. Knoxville News Sentinel. Retrieved from http:// www.knoxnews.com/govolsxtra/other-sports/secrecy-101-in-college-athletics 
Salzwedel, M.R., \& Ericson, J. (2003). Cleaning up Buckley: How the family educational rights and privacy act shields academic corruption in college athletics. Wisconsin Law Review, 1, 1053-1113.

State ex rel. ESPN, Inc. v. Ohio State University, 970 N.E.2d 939 (Ohio 2012).

State ex rel. The Miami Student v. Miami University, 79 Ohio St. 3d 168, 680 N.E.2d 956 (Ohio 1997).

Strentz, H. (2001, February). Law compounds Drake basketball/GPA woes. Iowa Newspaper Association Bulletin.

Student Press Law Center. (n.d.). Retrieved from http://www.splc.org

The News \& Observer Publishing Co. v. Baddour, 10 CVS 1941. Memorandum re decision on plaintiffs' motion for summary judgment and defendants' motion for summary judgment (Orange County Superior Court, 2011, April).

The News \& Observer Publishing Co. v. Baddour, 10 CVS 1941. Memorandum re decision on plaintiffs' motion for summary judgment and defendants' motion for summary judgment (Orange County Superior Court, 2012, August).

Todd, T. (2013, December). Jerian Grant withdraws from Notre Dame, cites academic issues. SBNation.com. Retrieved from http://www.sbnation.com/college-basketball/2013/12/22/5236686/jerian-grant-notre-dame-basketball-withdrawal

University of North Carolina. (2015a). Public Records Requests October 1 through November 30, 2014. Retrieved from http://publicrecords.unc.edu/search-results/?sd=2014-1001\&ed=2014-12-31\&k=WRAL\#038; $\mathrm{ed}=2014-12-31 \& \mathrm{k}=\mathrm{WRAL}$

University of North Carolina. (2015b). Public Record Requests, ID Nos. 150167 \& 150183. Retrieved from http://publicrecords.unc.edu/public-records/

United States v. Miami University, 294 F.3d 797 (6th Cir. 2002).

U.S. Department of Education. (2004). Legislative history of major FERPA provisions. Retrieved from http://www2.ed.gov/policy/gen/guid/fpco/ferpa/leg-history.html

U.S. Department of Education. (2011). FERPA general guidance for students. Retrieved from http://www2.ed.gov/policy/gen/guid/fpco/ferpa/students.html

U.S. Department of Education. (2012). Model notice for directory information. Retrieved from http://www2.ed.gov/policy/gen/guid/fpco/ferpa/mndirectoryinfo.html

U.S. Department of Education. (2014a). Family Educational Rights and Privacy Act (FERPA). Retrieved from http://www2.ed.gov/policy/gen/guid/fpco/ferpa/index.html

U.S. Department of Education. (2014b). About the Family Policy Compliance Office (FPCO). Retrieved from http://www2.ed.gov/policy/gen/guid/fpco/index.html

"University Responds." (n.d.). University responds to public records requests for legal, communications firm expenses. Retrieved from http://carolinacommitment.unc.edu/ updates/university-responds-to-public-records-requests-for-legal-communicationsfirm-expenses/

Wainstein, K.L., Jay, A.J., III, \& Kukowski, C.D. (2014). Investigation of irregular classes in the department of African and Afro-American Studies at the University of North Carolina at Chapel Hill. New York, NY.

Wolverton, B. (2008, September 5). Rise in fancy academic centers for athletes raises questions of fairness. The Chronicle of Higher Education. Retrieved from http://chronicle. com/article/Rise-in-Fancy-Academic-Centers/13493/

Wolverton, B. (2015, January 21). NCAA says it's investigating academic fraud at 20 colleges. The Chronicle of Higher Education. Retrieved from http://chronicle.com/article/ NCAA-Says-It-s-Investigating/151315/

Yin, R.K. (2003). Case study research: Designs and methods (3rd ed.). Thousand Oaks, CA: SAGE Publications.

Zhang, J. (2014, January). N\&O sues UNC for withholding records in academic scandal. Duke Chronicle. Retrieved from http://www.dukechronicle.com/articles/2014/01/30/ no-sues-unc-withholding-records-academic-scandal 